\title{
Horizontal transmission of disseminated neoplasia in the widespread clam Limecola balthica from the Southern Baltic Sea
}

\author{
Alicja Michnowska ${ }^{1}$, Samuel Hart ${ }^{2}$, Katarzyna Smolarz ${ }^{1}$, Anna Hallmann ${ }^{3}$, and Michael J \\ Metzger ${ }^{4}$ \\ ${ }^{1}$ University of Gdansk Institute of Oceanography \\ ${ }^{2}$ Pacific Northwest Research Institute \\ ${ }^{3}$ Medical University of Gdansk \\ ${ }^{4}$ Pacific Northwest Diabetes Research Institute
}

February 4, 2022

\begin{abstract}
Disseminated neoplasia (DN) is one of the most challenging and unrecognised diseases occurring in aquatic fauna. It has been diagnosed in four bivalve species from the Gulf of Gdańsk (Southern Baltic Sea) with the highest frequency in Limecola balthica (formerly Macoma balthica), reaching up to $94 \%$ in some populations. The aetiology of DN in the Baltic Sea has not yet been identified, with earlier studies trying to link its occurrence with environmental pollution. Taking into account recent research providing evidence that DN is horizontally transmitted as clonal cells between individuals in some bivalve species, we aimed to test whether DN is a transmissible cancer in the population of L. balthica from the Gulf of Gdańsk highly affected with cancer. We examined mitochondrial cytochrome c oxidase I (mtCOI) and elongation factor $1 \alpha(\mathrm{EF} 1 \alpha)$ sequences of genomes obtained from haemolymph and tissues of neoplastic and healthy individuals. Sequence analysis resulted in detection of an independent transmissible cancer lineage occurring in 4 neoplastic clams that is not present in healthy animals. This paper describes the first case of transmissible DN in the clam L. balthica providing further insights for studies on this disease.
\end{abstract}

Alicja Michnowska ${ }^{1, *}$, Samuel F. M. Hart ${ }^{2,3}$, Katarzyna Smolarz ${ }^{1}$, Anna Hallmann ${ }^{4}$, Michael J. Metzger 2,3

Horizontal transmission of disseminated neoplasia in the widespread clam Limecola balthica from the Southern Baltic Sea

${ }^{1}$ Department of Marine Ecosystems Functioning, Institute of Oceanography, Faculty of Oceanography and Geography, University of Gdańsk, Piłsudskiego 46, 81-378 Gdynia

${ }^{2}$ Pacific Northwest Research Institute, 720 Broadway, Seattle, WA 98122

${ }^{3}$ Molecular and Cellular Biology Program, University of Washington, 1959 NE Pacific Street, HSB T-466, Seattle, WA 98195

${ }^{4}$ Department of Pharmaceutical Biochemistry, Medical University of Gdańsk, Debinki 1, 80-211 Gdańsk

*e-mail:alicja.michnowska@phdstud.ug.edu.pl

\section{Abstract}

Disseminated neoplasia (DN) is one of the most challenging and unrecognised diseases occurring in aquatic fauna. It has been diagnosed in four bivalve species from the Gulf of Gdańsk (Southern Baltic Sea) with the highest frequency in Limecola balthica (formerly Macoma balthica), reaching up to $94 \%$ in some populations. 
The aetiology of DN in the Baltic Sea has not yet been identified, with earlier studies trying to link its occurrence with environmental pollution. Taking into account recent research providing evidence that DN is horizontally transmitted as clonal cells between individuals in some bivalve species, we aimed to test whether DN is a transmissible cancer in the population of L. balthica from the Gulf of Gdańsk highly affected with cancer. We examined mitochondrial cytochrome c oxidase I (mtCOI) and elongation factor $1 \alpha(E \Phi 1 a)$ sequences of genomes obtained from haemolymph and tissues of neoplastic and healthy individuals. Sequence analysis resulted in detection of an independent transmissible cancer lineage occurring in 4 neoplastic clams that is not present in healthy animals. This paper describes the first case of transmissible DN in the clam L. balthica providing further insights for studies on this disease.

\section{Introduction}

Disseminated neoplasia (DN), also known as clam leukaemia, disseminated sarcoma, and haemic/systematic/haematopoietic neoplasia, is a cancerous disease observed in over 30 species of bivalves worldwide (Wołowicz et al. 2005, Carballal et al. 2015). The disease can act as a dangerous epizootic event leading to mass mortality in some populations (Farley et al. 1991, Muttray et al. 2012, Benabdelmouna \& Ledu 2016) affecting commercially used species and leading to ecosystem unbalance (Barber et al. 2004). DN is a proliferative disorder of circulating cells predominantly found in the haemolymph. Neoplastic cells (NCs) are morphologically and physiologically distinct from normal haemolymph cells, which are gradually replaced with NCs during cancer progression. NCs, most likely of haemocyte origin, are characterized by high aneuploidy level, higher nucleus-cytoplasm volume ratio and increased proliferative activity resulting in nuclear and cellular hypertrophy (Thriot-Quiévreux \& Wołowicz 1996, Smolarz et al. 2005ac, Smolarz et al. 2006a, Carella et al. 2013, Carella et al. 2017). Yet, alteration level in specific physiological and biochemical parameters of NCs differ between species (Barber et al. 2004, Le Grand et al. 2014, Carballal et al. 2015, Odintsova 2020). During cancer progression NCs are able to disseminate into tissues of an organism, leading to histological modifications, tissue/organ malfunction and eventually to death of an animal (Barber 2004, Carella et al. 2015, Carballal et al. 2015).

DN has been diagnosed in four bivalve species in the Gulf of Gdańsk (Southern Baltic Sea): Limecola (Macoma ) balthica ,Mya arenaria, Mytilus trossulus and Cerastoderma glaucum (Thiriot-Quiévreux \& Wołowicz 1996, Wołowicz et al. 2005, Smolarz et al. 2005bd, Smolarz et al. 2006b, Ogrodowczyk 2017). The frequency of cancer differs between species, population of a species, sampling sites, and sampling year, with the highest prevalence inL. balthica (the Baltic clam) reaching as high as $94 \%$ in populations inhabiting deeper (30-85 m) parts of the gulf (Thiriot-Quiévreux \& Wołowicz 1996, Thiriot-Quiévreux \& Wołowicz 2001). L. balthica is one the most widespread bivalve species found in the Baltic Sea area, but it is also commonly found in the temperate and arctic coastal waters of the North Atlantic and North Pacific (Budd \& Rayment 2001). The Baltic clam plays a key role in various ecosystems, but due to the species' adaptive potential it is of particular importance in ecosystems characterized by changeable and unfavourable conditions such as low salinity, contamination and/or temporal/seasonal oxygen depletion, all found in the Baltic Sea (Segerstråle 1957, Janas et al. 2004, Janas et al. 2007). Earlier studies linked DN incidence with adverse environmental conditions and/or anthropogenic pollution as contaminants such as heavy metals, polycyclic hydrocarbons (WWA) and persistent organic pollutants (POPs) were previously proposed as ultimate carcinogenic factors in DN induction (reviewed in: Barber 2004, Carballal et al. 2015). However, those studies do not indicate any clear correlation between any specific environmental factor and cancer occurrence (Smolarz et al. 2005, Wołowicz et al. 2005, Smolarz et al. 2006) suggesting that DN in these clams may have a different cause.

In recent years, it was discovered that some types of cancer in animals can be explained by non-viral infectious aetiology, with cancerous cells being transmitted between individuals as an allograph that further leads to cancer development. Transmissible cancer based on clonal malignant cell transmission is generally considered to be a rare phenomenon, until now, observed only in exceptional and distinctive cases. To date there are three recognized types of cancer with transmissible aetiology: canine transmissible venereal tumour (CTVT) (Murgia et al. 2006, Rebbeck et al. 2009), devil facial tumour disease (DFTD) (Pearse et al. 2006), and bivalve transmissible neoplasia $(\mathrm{BTN})$. BTN is a transmissible form of $\mathrm{DN}$, and BTN lineages have been 
found in seven bivalve species: soft-shell clam M. arenaria from Atlantic coast of North America (Metzger et al. 2015); Cerastoderma edule and Polititapes aureus from Galician coast of Spain (Metzger et al. 2016); and four species of Mytilus mussels from around the world, M. trossulus, M. edulis, M. chilensis and M. galloprovincialis (Yonemitsu et al. 2019, Skazina et al. 2021, Hammel et al. 2021). DN transmission in the above-mentioned bivalve species was confirmed using polymorphic microsatellite alleles of nuclear DNA and sequence analysis of mitochondrial and nuclear genes. These analyses found that the genomes of NCs were different from the genomes of the hosts, yet nearly identical to each other, indicating infectious nature of the disease.

The Gulf of Gdańsk, located in the southern part of the Baltic Sea, with its specific geomorphological structure, low salinity and low diversity constitutes an excellent biological model to study horizontal transfer of cancer cells. One of the four bivalve species occurring here,L. balthica, due to its widespread occurrence and high cancer prevalence, can be considered as a valuable model organism in DN and BTN research. Taking into account the unsolved basis of this commonly diagnosed cancer in L. balthica and the findings that DN in many species have been found transmissible (Metzger \& Goff 2016), in this study we aim to use genomic analysis to test whether DN in L. balthica inhabiting the southern Baltic Sea (Gulf of Gdańsk) is a BTN. This will increase our knowledge of transmissible cancer and the ways in which cancer can affect animals in the environment.

\section{Materials and methods}

\subsection{Clam collection and maintenance}

Clams (approx. 100) were collected in February $2019^{\text {th }}$ from a sampling site H45 located in the Gulf of Gdańsk (southern Baltic Sea) at $45 \mathrm{~m}$ depth. The selected area has been reported to have the highest prevalence of DN in L. balthica, as described in: Smolarz et al. (2005bd) and Ogrodowczyk (2017) (Fig. 2.1 ). Clams exceeding $10 \mathrm{~mm}$ in size (large enough for haemolymph withdrawal) were selected from the sediment samples collected with a Van Veen grabber on board of the $r v$ Oceanograf. Transport and laboratory set-up were adjusted to imitate in situ conditions. Bivalves were kept in $15 \mathrm{~L}$ tanks (approximately 50 clams per one tank) filled with seawater collected at sea bottom from the sampling site for time not exceeding five days. No sediment substrate was added to tanks with animals for purification purposes.

\subsection{Tissues processing and DN diagnostics}

\section{Samples for molecular analysis}

Haemolymph was withdrawn directly from the adductor muscle using a Hamilton microsyringe. Syringes were thoroughly cleaned with $10 \%$ hydrochloric acid and washed in $70 \%$ ethanol and deionized water between individuals to avoid contamination. Haemolymph volume varied between specimens with range of approximately 20 - $100 \mu \mathrm{l}$. Equivalent volume of absolute ethanol was added to each haemolymph sample. Foot muscle tissue was dissected from each individual and put into $200 \mu \mathrm{l}$ of absolute ethanol. Both haemolymph and soft tissue samples were stored at $-20^{\circ} \mathrm{C}$ until the time of transport to our partner laboratory (PNRI, Seattle, USA) where they were further processed for molecular analysis. Ethanol-fixed samples were transported in the time not exceeding two days via plane in room temperature and after arrival were stored at $-20^{\circ} \mathrm{C}$.

\section{Histological diagnostics}

The remaining bodies of each clam were dissected and fixed with $5 \mathrm{ml}$ of Davidson fixative (formaldehyde, acetic acid, ethanol) that was replaced with $4 \%$ phosphate-buffered formaldehyde after 48 hours. Fixed tissues were then dehydrated in increasing concentration of alcoholic solutions, cleaned in xylenes, and embedded in histological grade paraffin wax. Histological blocks were cut into $3 \mu \mathrm{m}$ sections on a microtome (RM2245, Leica) and transferred onto microscopic slides that were later dried in $60^{\circ} \mathrm{C}$ for paraffin dissolution. Prepared sections were dyed using standard Harris' haematoxylin and alcoholic eosin stain (H\&E) protocol for histological visualisation, mounted with xylene-based medium and investigated under light microscope. Only clams with infiltration of NCs observed in more than one tissue type, and prevalence of cancerous cells 
$>50 \%$ were classified as DN-positive (Fig. 2.2 ). Diagnosis resulted in selection of 4 neoplastic (labelled as $\# 143,144,157,158)$ and 2 healthy $(\# 88,89)$ individuals as references. Haemolymph and muscle samples from selected individuals were further used for molecular analysis.

\subsection{Molecular analysis}

\section{DNA extraction}

DNA was extracted from ethanol-fixed haemolymph and tissue samples using DNeasy Blood and Tissue Kit (Qiagen). Haemocyte pellet was obtained by spinning the cells down with $1400 \times$ g speed for $10 \mathrm{~min}$. After lysis of tissues, P3 Buffer (Qiagen) was added to precipitate out polysaccharides that inhibit PCR reactions. Further extraction was performed in accordance with the protocol provided by manufacturer.

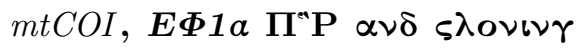

Primers and annealing temperatures are listed in Tab. 2.3. PCR amplification for mitochondrial cytochrome oxidase c I ( $m t C O I$ ) and elongation factor $1 \alpha(E \Phi 1 a)$ loci was done using Q5 Hot Start High-Fidelity DNA Polymerase (NEB) with a $30 \mathrm{~s}$ extension time and annealing performed at $50^{\circ} \mathrm{C}$. PCR reaction mix consisted of buffer $(5 \mathrm{x}$, Qiagen, $5 \mu \mathrm{l})$, dNTPs $(0.5 \mu \mathrm{l})$, forward and reverse primers $(1.25 \mu \mathrm{l}$ of $10 \mu \mathrm{M}$ for both), $0.25 \mu$ polymerase and ddH2O (to $25 \mu \mathrm{l}$ ). 'Pan-molluscan' barcoding primers (Folmer et al. 1994) did not amplifymtCOI allele in L. balthica. Therefore, degenerate primers designed to match the same region of L. balthica $m t C O I$ were used (Metzger et al. 2018), detailed in Tab. 2.3. We identified two transcripts with

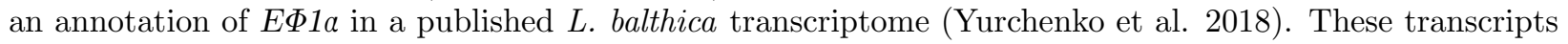
aligned to one another with a high degree of polymorphism, indicating these may represent multiple copies of EF1 -like genes in the L. balthica genome rather than different isoforms or haplotypes. We assumed intron placement would likely be conserved in the E$\Phi 1$ a gene among bivalves, so we aligned these transcripts to an oyster genome (Crassostrea_gigas : oyster_v9 genome version) E\$1aregion using Geneious alignment with default settings. We then chose primer sites to target coding sequence and amplify across the 5 th intron. We

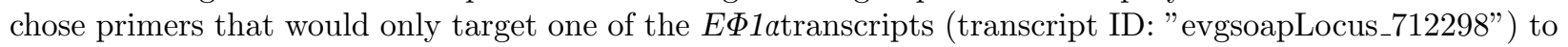

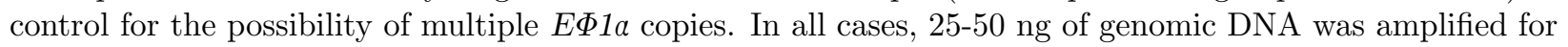
35 cycles with initial denaturation performed at $98^{\circ} \mathrm{C}$ for $30 \mathrm{~s}$.

PCR products were gel extracted using QIAquick Gel Extraction Kit (Qiagen) and either directly sequenced, or, when multiple alleles at a locus could not be resolved by direct sequencing, were cloned using the Zero Blunt TOPO PCR Cloning Kit (Invitrogen). Plasmids were transformed into TOP10 or DH5 $\alpha$ competent Escherichia coli (Invitrogen) and at least 6 clones were picked for further sequencing using M13F and M13R

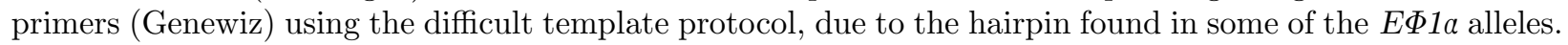
In cases where a single clone was sequenced that was 1 SNP different from another clone found in multiple clones from the same animal, or a single clone was found to be consistent with recombination between two other clones found in multiple clones in the same animal, the single clones were assumed to be PCR artefacts. In cases where differences were found between the sequence results of haemolymph and tissue from the same individual, the alleles found more often in the haemolymph sample were called as the haemolymph alleles and those found more often in tissue were considered the tissue alleles. The primer binding regions were excluded from sequence analysis and all unique alleles were identified.

\section{Phylogenetic analysis}

Sequences were aligned manually in BioEdit (7.1 version) software (Hall 1999). Maximum likelihood phylogenetic trees were generated using PhyML (3.0 version) (Guindon et al. 2010) performing 100 bootstrap replicates with automatic model selection through Akaike Information Criterion. Trees were visualized using FigTree (1.4.4 version) software (Rambaut 2010).

\section{Results}

\subsection{Phylogenetic analysis of $m t C O I$ gene}


Sequence analysis of $m t C O I$ resulted in identification of six alleles present in tested samples and revealed that the haemocyte genome does not correspond to the genome of the host animal in any clams diagnosed with DN, whereas alleles in healthy animals represent the exact same DNA sequence in both sample types. These results are supported by high $(>70)$ bootstrap values (Fig. 3.1 ).

Two mtCOI alleles, 'a' and 'b', consistent between host tissue and haemolymph within an individual, were identified in healthy clams. Alleles ' $c$ ', 'e', and 'f' discovered in solid tissue DNA of neoplastic animals were not found in their haemolymph equivalents. Allele ' $\mathrm{d}$ ' present in haemolymph of neoplastic animals was identical between all four individuals diagnosed with DN and was distinct from both healthy alleles and alleles found in the DNA of hosts with neoplasia. All identified mtCOI alleles are listed in Tab. 3.1 .

\subsection{Phylogenetic analysis of EF1 agene}

Eight E\$1a alleles were identified through sequence analysis and cloning with the resulting tree supporting the $m t C O I$ phylogenetic analysis, showing variations between genomes of haemolymph and host tissue in neoplastic clams (Fig. 3.2).

$E \Phi 1 a$ alleles 'b', 'd', and 'h' represent healthy host alleles, as they were found to be identical between

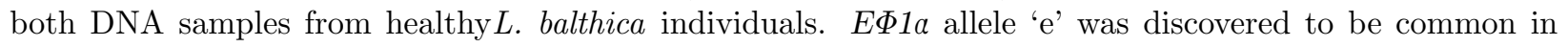
haemolymph DNA of all clams diagnosed with DN and was not present or found at a much lower level

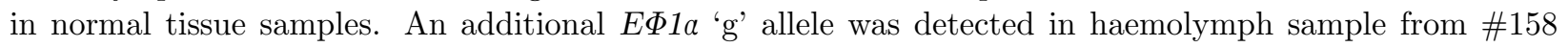
individual that was not present in the solid tissue of this specimen, although it was found in tissue DNA of another neoplastic clam. Two different alleles, 'g"' and 'i', were found in two neoplastic hosts' DNA (Tab. 3.2 ).

\section{Discussion}

Results of phylogenetic analysis of both mitochondrial ( $m t C O I)$ and nuclear (E\$1a) genes show that

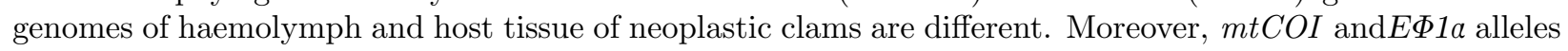
found in haemolymph DNA of individuals diagnosed with DN are common between all of them, suggesting the existence of an independent cell line shared between these cancerous clams. Such results indicate the existence of at least one horizontally transmitted cancer lineage in the L. balthica population from the Baltic Sea, in accordance with original studies documenting first evidence of BTN in bivalves (Metzger et al. 2015, Metzger et al. 2016) that also formulated the basis of molecular identification of BTN. All tested neoplastic clams were discovered to share a common allele in both loci investigated, but one of the individuals was also identified with a distinct $E \Phi 1 a$ allele in the haemolymph genotype that was not present in host genome. This most likely indicates the presence of somatic mutation in the NCs and the loss of the second allele. Yet, at this stage the possible occurrence of another cancer lineage in the tested population cannot be excluded either. Genome variation between different types of tissue within the same organism can occur, especially in tissues characterized by elevated mitotic activity, such as hepatopancreas or gills, due to a potential accumulation of mutations resulting in somatic mosaicism (O'Huallachain 2012), but the chance of different individuals developing the same consistent alleles within multiple conserved genes is very low. Variations in coding sequences can be observed in cases of cancer development in higher organisms (O'Huallachain 2012, GTEx Consortium 2017). Genomic rearrangement within single individuals has not been described yet in invertebrates, although some genetic variability is reasonably expected in proliferative disorders such as DN, due to poly- and aneuploidy of cancerous cells and their high mutative potential (Diaz et al. 2010, Ruiz et al. 2013). However, taking into the account the nearly perfect similarity of alleles occurring in haemolymph of neoplastic $L$. balthicaindividuals we conclude that the recognized lineage originated from a single organism and are now transmitted within the gulf population of this species.

Phylogenetics also revealed natural polymorphism occurring within the population, as alleles found in both $m t C O I$ and $E \Phi 1 a$ loci of healthy clams differ between individuals. L. balthica is generally characterized as a species of high genetic variability among all of its populations worldwide, mostly associated with its local adaptations for environmental conditions (Yurchenko et al. 2018). Such variability is also observed in populations inhabiting the Gulf of Gdańsk, where distinct genetic structures are observed between shallow 
and deep sites (Becquet et al. 2013, Lasota et al. 2018) as populations inhabiting deeper areas are partially isolated by straitened water mixing, sea currents, and seasonally by thermocline and halocline (Kowalewski 1997, Kruk-Dowgiałło \& Szaniawska 2008). A possible bottleneck effect that some Baltic L. balthica populations may have undergone (Belov 2011) can affect their susceptibility for evolving transmissible cancer lineages. These results suggest that BTN affecting the Baltic clam may also be present in other clam populations on a worldwide scale due to an extensive geographical range of the species and its evolutionary history (Väinölä 2003, Pante et al. 2012). DN has been already diagnosed in various L. balthica populations, e.g. from Finnish coast of Baltic Sea (Pekkarinen 1993), Wadden Sea (Dairain et al. 2020), and Chesapeake Bay (Christensen et al. 1974), although this paper is the first confirming clonal aetiology of this disease.

The L. balthica population chosen for our study comes from a site (H45) that is considered a relatively deep $(45 \mathrm{~m})$ sampling area in the gulf and is characterized by historically highest DN frequency in this species, ranging from 25 to 94\%, depending on sampling year (Thriot-Quiévreux \& Wołowicz 2001, Smolarz et al. 2005bd, Ogrodowczyk 2017). This population has been under investigation for many years, not only in terms of DN occurrence, but also because of adverse environmental conditions that occur in the site area, such as oxygen depletion and/or presence of toxic hydrogen sulphide, either temporal, seasonal or constant in some years, as well as anthropogenic pollution consisting of, among others, heavy metals, aromatic polycyclic hydrocarbons (WWAs), or polychlorinated biphenyls (PCBs), staying at a relevant level in water and/or sediments throughout the years (Renner et al. 1998; Pazdro et al. 2004, Kot-Wasik et al. 2004, Zaborska et al. 2019). Such challenging environmental characteristics, along with ecological, individual and genetic variations (e.g. trophic position, sex, fitness, genetic structure) were previously proposed to be carcinogenic factors in DN induction in the Baltic Sea (Wołowicz et al. 2005). Although our study confirms the transmissible character of $\mathrm{DN}$ inL. balthica, the role of potential pollution and other environmental factors on cancer development and susceptibility should not be overlooked. Chronic and acute exposure to various pollutants, temporal anoxic conditions, immunosuppression and co-occurring oxidative stress may potentially increase vulnerability of bivalves to contagious cancer cells (Metzger \& Goff 2016) and/or induce the expression of genome-integrated retrovirus elements, as some studies also suggest the role of transmissible retroelements in BTN induction (Arriagada et al. 2014).

NCs isolated from L. balthica are described as highly aneuploid with high disseminating potential, enormous and pleomorphic nuclei, and low amount of cytoplasm (Thriot-Quiévreux \& Wołowicz 1996, Thriot-Quiévreux \& Wołowicz 2001, Smolarz et al. 2005ac; Smolarz et al. 2006a). These features of NCs are similar in all bivalve species (Barber et al. 2004, Carballal et al. 2015) suggesting some universal characteristics of DN within Bivalvia. Most probably, the cellular mechanism by which NCs are able to be transplanted between individuals evading immunological signalling is also common between taxa. Due to the absence of adaptive immunity in bivalves, biochemically changed NCs do not provoke effective pathogen-directed defence systems in these animals and those cells are able to clone themselves and disseminate into the tissues of other hosts (Metzger \& Goff 2016, Ujvari et al. 2016). The mechanism of NCs transmission is not fully described yet, but it is believed that single clonal cancerous cells that originate in one neoplastic individual are expelled from its body in, either by direct release of DNA from heavily neoplastic animals (Giersch et al. 2021) or possibly through spawning or death events, and are then transmitted to other individual(s) via seawater uptake. This hypothesis is supported by studies showing successful inoculation of NCs and/or haemolymph from neoplastic to healthy bivalve through injection which resulted in further DN development and also transmission of NCs through cohabitation in different bivalve species (thoroughly discussed in Carballal et al. 2015 and Metzger et al. 2015). The studies of viability of NCs from M. arenaria shows that these cells are able to survive in the water column for several hours (Sunila \& Farley 1989) or even up to 8 weeks in lower temperatures (Giersch et al. 2021). The success of implantation to another organism is determined by the water circulation and density of animals (Elston et al. 1990) and most probably with the filtrating potential of species. It was also reported that NCs from theMytilus BTN cell line (MtrBTN2) can survive outside of host's organism up to 6 days (Burioli et al. 2021) giving plenty of time for potential transmission via water filtration. To date, there is no published paper considering L. balthica NCs viability, but in our routine lab work we observe that those cells can survive at least two hours when kept in an isotonic solution 
(Czajkowska 2021). Ecological consequences of DN/BTN can be extremely severe as it was documented that some populations affected with this cancer experience increased mortality, even mass mortality in some cases (Farley et al. 1986, Farley et al. 1991, Muttray et al. 2012, Benabdelmouna \& Ledu 2016) with critical impact on surrounding ecosystems. Such events are also observed in L. balthica from Gulf of Gdańsk, especially from the H45 population that is investigated here, which is affected by mass mortality occurring in bi- or triennial periods lead by an increase in DN prevalence (Sokołowski et al. 2004, Wołowicz et al. 2005).

As stated previously, disseminated neoplasia has also been diagnosed in three other bivalve species from the Gulf of Gdańsk, Poland, namelyM. arenaria , C. glaucum, and M. trossulus, although at a much lower prevalence (Smolarz et al. 2005d; Smolarz et al. 2006b; Ogrodowczyk 2017). Further studies are needed to determine if DN in these species is also a BTN and if cancer contagiousness is related to intra- or interspecies transmission.

Our study presents the first evidence of transmissible aetiology of this cancer in L. balthica, and provides a base for further investigation of the severity of this transmissible cancer in other $L$. balthica populations as well as in other Baltic species affected with DN. Adding L. balthica to the list of BTN-affected species resulting in overall eight $\mathrm{BTN}$-affected species and nine cancer lineages, making the transmissible cancer even more common in the biological world than it was thought earlier. The widespread occurrence of BTN in multiple genera is an interesting phenomenon in cancer biology, and this phenomenon has potential to be a model disease (Aguilera 2017, Fernández Robledo et al. 2019) for in-depth understanding of leukemic diseases in other organisms, including humans.

\section{Acknowledgments}

This study was financed by National Centre of Science (Poland) within Harmonia 9 grant "Contagious neoplasia? The role of horizontal transmission of cancer cells in aetiology of disseminated neoplasia in clams from the Gulf of Gdańsk", grant number: UMO-2017/26/M/NZ8/00478 and National Institutes of Health support to Michael Metzger (K22 CA226047) and Sam Hart (T32-GM007270, T32-HG000035).

We would like to thank Dr Justyna Świeżak (University of Gdańsk) for help in sample collection and processing, Marisa Yonemitsu (Pacific Northwest Research Institute and University of Washington) for laboratory assistance and guidance and Rachael Giersch (Pacific Northwest Research Institute) for help in manuscript editing.

\section{References}

Aguilera F. (2017). Neoplasia in mollusks: what does it tell us about cancer in humans? - A review. Journal of Genetic Disorders , 1, 1-10.

Arriagada G., Metzger M. J., Muttray A.F., Sherry J., Reinisch C., Street C., Lipkin W. I., Goff S. P. (2014). Activation of transcription and retrotransposition of a novel retroelement, Steamer, in neoplastic hemocytes of the mollusc Mya arenaria .Proceedings of National Academy of Sciences USA, 111, 14175-14180.

Barber B.J. (2004). Neoplastic diseases of commercially important marine bivalves. Aquatic Living Resources , 17, 449-466.

Becquet V., Lasota R., Pante E., Sokołowski A., Wołowicz M., Garcia P. (2013). Effects of fine-scale environmental heterogeneity on local genetic structure in Macoma balthica from the Gulf of Gdańsk (Southern Baltic Sea). Hydrobiologia , 714, 61-70.

Belov K. (2011). The role of the major histocompatibility complex in the spread of contagious cancers. Mammalian Genome, 22, 83-90.

Benabdelmouna A., Ledu C. (2016). The mass mortality of blue mussels (Mytilus spp.) from the Atlantic coast of France is associated with heavy genomic abnormalities as evidenced by flow cytometry. Journal of Invertebrate Pathology, 138, 30-38. 
Budd G. C., Rayment W. J. (2001). Limecola balthica Baltic tellin(inn: Tyler-Walters H. and Hiscock K. (eds) Marine life information network: biology and sensitivity key information reviews(on-line), Plymouth: Marine Biological Association of the United Kingdom).

Carballal M. J., Barber B. J., Iglesias D., Villalba A. (2015). Neoplastic diseases of marine bivalves. Journal of Invertebrate Pathology, 131, 83-106.

Carella F., Figueras A., Novoa B., De Vico G. (2013). Cytomorphology and PCNA expression pattern in bivalves Mytilus galloprovincialis andCerastoderma edule with haemic neoplasia. Diseases of Aquatic Organisms , 105, 81-87.

Carella F, Feist SW, Bignell JP, De Vico G (2015) Comparative pathology in bivalves: Aetiological agents and disease processes. J Invertebr Pathol 131: 107-120.

Carella F., De Vico G., Landini G. (2017). Nuclear morphometry and ploidy of normal and neoplastic haemocytes in mussels. PLoS One, e0173219.

Christensen D. J., Farley C. A., Kern F. G. (1974). Epizootic neoplasms in the clam Macoma balthica (L.) from Chesapeake Bay.Journal of the National Cancer Institute, 52. 1739-1749.

Czajkowska K. (2021). Cohabitation as an element of horizontal transfer of neoplastic cells in Limecola balthica (in Polish, Master's thesis, Department of Marine Ecosystems Functioning, University of Gdańsk).

Dairain A., Engelsma M. Y., Drent J., Dekker R., Thieltges D. W. (2020). High prevalence of disseminated neoplasia in the Baltic tellinLimecola balthica in the Wadden Sea. Diseases of Aquatic Organisms , 138, 89-96.

Diaz S., Cao A., Villalba A., Carballal M. J. (2010). Expression of mutant protein p53 and Hsp70 and Hsp 90 chaperones in cockles Cerastoderma edule affected by neoplasia. Diseases of Aquatic Organisms , 90, 215-222.

Elston R. A., Drum A. S., Allen S. K. (1990). Progressive development of circulating polyploid cells in Mytilus with hemic neoplasia.Diseases of Aquatic Organisms , 8, 51-59.

Farley C. A., Otto S. V., Reinisch C. L. (1986). New occurrence of epizootic sarcoma in Chesapeake Bay soft shell clams, Mya arenaria . Fishery Bulletin, 84, 851-857.

Farley C. A., Plutschak D. L., Scott R. F. (1991). Epizootiology and distribution of transmissible sarcoma in Maryland softshell clams, Mya arenaria , 1984-1988. Environmental Health Perspectives , 90, 35-41.

Fernández Robledo J. A., Yadavalli R., Allam B., Pales Espinosa E., Gerdol M., Greco S., Stevick R. J., Gómez-Chiarri M., Zhang Y., Heil C. A., Tracy A. N., Bishop-Bailey D., Metzger M. J. (2019). From the raw bar to the bench: Bivalves as models for human health.Developmental $\&$ Comparative Immunology , 92, $260-282$.

Folmer O., Black M. B., Wr H., Lutz R., Vrijenhoek R. C. (1994). DNA primers for amplification of mitochondrial cytochrome $\mathrm{C}$ oxidase subunit I from diverse metazoan invertebrates. Molecular Marine Biology and Biotechnology. 3, 294-299

Giersch R. M., Hart S. F. M., Reddy S. G., Yonemitsu M. A., Orellana Rosales M. J., Korn M., Galeta B. M., Countaway P. D., Fernández Robledo J. A., Metzger M. J. (2021). Survival and detection of bivalve transmissible neoplasia from the soft-shell clam Mya arenaria(MarBTN) in seawater. BioRxiv , https://doi.org/10.1101/2021.12.25.473725.

GTEx Consortium. (2017). Genetic effects on gene expression across human tissues. Nature 550, 204-213.

Guindon S., Dufayard J. F., Lefort V., Anisimova M., Hordjik W., Gascuel O. (2010). New algorithms and methods to estimate maximum-likelihood phylogenies: assessing the performance of PhyML 3.0. Systematic Biology , 59, 307-321. 
Hall T. A. (1999). BioEdit: A user-friendly biological sequence alignment editor and analysis program for Windows 95/98/NT.Nucleic Acids Symposium Series . 41, 95-98.

Hammel M., Simon A., Arbiol C., Villalba A., Burioli E. A. V., Pepin J-F., Lamy J-B., Banabdelmouna A., Bernard I., Houssin M., Charriere G. M., Destomieux-Garzon D., Welch J. J., Metzger M. J., Bierne N. (2021). Prevalence and polymorphism of a mussel transmissible cancer in Europe.Molecular Ecology , 00, $1-16$.

Janas U., Wocial J., Szaniawska A. (2004). Seasonal and annual changes in the macrozoobenthic populations of the Gulf of Gdańsk, with respect to hypoxia and hydrogen sulphide. Oceanologia, 46, 85-102.

Janas U., Nowodworska E., Bezdzietny I. (2007). Fitness and chemical composition of the Baltic clam Macoma balthica (Linnaeus, 1758) from sulphidic habitats in the Gulf of Gdańsk (Southern Baltic).Thermochimica Acta , 458, 112-117.

Kot-Wasik A., Debska J., Namieśnik J. (2004). Monitoring of organic pollutants in coastal waters of the Gulf of Gdańsk, Southern Baltic.Marine Pollution Bulletin, 49, 264-276.

Kowalewski M. (1997). A three-dimensional hydrodynamic model of the Gulf of Gdańsk. Oceanological Studies, 26, 77-98.

Lasota R., Sokołowski A., Smolarz K., Sromek L., Dublinowska M. (2018). Multimarker response to salinity stress in two estuarine bivalves of different genetic diversity: Mya arenaria and Limecola balthica from the Gulf of Gdańsk (southern Baltic Sea).Invertebrate Biology , 137, 250-263.

Le Grand F., Soudant P., Siah A., Trembley R., Marty Y., Kraffe E. (2014). Disseminated neoplasia in soft-shell clam Mya arenaria : membrane lipid composition and functional parameters of circulating cells. Lipids , 49, 807-818.

Metzger M. J,, Reinisch C,, Sherry J,, Goff S, P. (2015). Horizontal transmission of clonal cancer cells causes leukemia in soft-shell clams. Cell , 161, 255-263.

Metzger M. J., Goff S. P. (2016). A sixth modality of infectious disease: contagious cancer from devils to clams and beyond. PLoS Pathogens, 12, e1005904.

Metzger M. J., Villalba A., Carballal M. J., Iglesias D., Sherry J., Reinisch C., Muttray A. F., Baldwin S. A., Goff S. P. (2016). Widespread transmission of independent cancer lineages within multiple bivalve species. Nature, 534, 705-709.

Murgia C., Pritchard J. K., Kim S. Y., Fassati A., Weiss R. (2006). Clonal origin and evolution of a transmissible cancer. Cell, 126, 477-487.

Muttray A., Reinisch C., Miller J., Ernst W., Gillis P., Losier M., Sherry J. (2012). Haemocytic leukemia in Prince Edward Island (PEI) soft shell clam (Mya arenaria ): spatial distribution in agriculturally impacted estuaries. Environmental Sciences , 424, 130-142.

O'Huallachain M., Karczewski K. J., Weissman S. M., Urban A. E., Snyder M. P. (2012). Extensive genetic variation in somatic human tissues.Proceedings of the National Academy of Scienses USA, 109, 18018-18023.

Odintsova N. A. (2020). Leukaemia-like cancer in bivalves. Russian Journal of Marine Biology 46: 59-67.

Ogrodowczyk I. (2017). Neoplasia in bivalves from Gulf of Gdańsk: comparative study (in Polish) (Master's thesis, Faculty of Oceanography and Geography of University of Gdańsk, Gdynia )

Pante E., Rohritsch A., Becquet V., Belkhir K., Bierne N., Garcia P. (2012). SNP detection from de novo transcriptome sequencing in Macoma balthica : marker development for evolutionary studies.PLoS One , 7, e52302.

Pazdro K. (2004). Persistent organic pollutants in sediments from the Gulf of Gdańsk. Rocznik Ochrona Środowiska , 6, 63-76. 
Pekkarinen M. (1993). Neoplastic disease in Macoma balthica(Bivalvia) of the Finnish coast. Journal of Invertebrate Pathology, 61, 138-146.

Rambaut A. (2010) FigTree v1.4.4 (Institute of Evolutionary Biology, University of Edinburgh, Edinburgh).

Rebbeck C. A., Thomas R., Breen M., Leroi A. M., Burt A. (2009). Origins and evolution of a transmissible cancer. Evolution, 63, 2340-2349.

Renner R. M., Glasby G. P., Szefer P. (1998). Endmember analysis of heavy-metal pollution in surficial sediments from the Gulf of Gdańsk and the southern Baltic Sea off Poland. Applied Geochemistry, 13, 313-318.

Ruiz P., Diaz S., Orbea A., Carballal M. J., Villalba A., Cajaraville M. P. (2013). Biomarkers and transcription levels of cancer-related genes in cockles Cerastoderma edule from Galicia (NW Spain) with disseminated neoplasia. Aquatic Toxicology, 136-137, 101-11.

Segerstråle S. G. (1957). Baltic Sea (in: Treatise on Marine Ecology and Paleoecology, Part I, Ecology , Hedgpeth J. W. ed, Geological Society of America, Memoir, 67, 751-800).

Shiewer U. (2008). Ecology of Baltic coastal waters . Berlin: Springer.

Shorthouse D. P. (2010). SimpleMappr, an online tool to produce publication-quality point maps(https://www.simplemappr.net).

Skazina M., Odintsova N., Ivanova M., Ivanova A., Vainola R., Strelkov P. (2021). First description of a widespread Mytilus trossulus -derived bivalve transmissible cancer lineage in M. trossulus itself. Scientific Reports , 11, 5809.

Smolarz K., Thriot-Quiévreux C., Wołowicz M (2005a) Recent trends in the prevalence of neoplasia in the Baltic clam Macoma balthica (L.) from the Gulf of Gdańsk (Baltic Sea). Oceanologia , 47, 61-74.

Smolarz K., Renault T., Soletchnik P., Wołowicz M. (2005b). Neoplasia detection in Macoma balthica from the Gulf of Gdańsk: comparison of flow cytometry, histology and chromosome analysis. Diseases of Aquatic Organisms , 65, 187-195.

Smolarz K., Renault T., Soletchnik P., Wołowicz M. (2005c). Survey for neoplasia in Macoma balthica from the Gulf of Gdańsk by flow cytometry. Diseases of Aquatic Organisms , 66, 41-56.

Smolarz K., Renault T., Wołowicz M. (2005d). Histology, cytogenetics and cytofluorymetry in diagnosis of neoplasia in Macoma balthica(Bivalvia, L.) from the southern Baltic Sea. Caryologia , 58, 212-219.

Smolarz K., Renault T., Wołowicz M. (2006a). Ultrastructural study of neoplastic cells in Macoma balthica (Bivalvia) from the Gulf of Gdańsk (Poland). Journal of Invertebrate Pathology, 92, 79-84.

Smolarz K, Wołowicz M, Stachnik M (2006b) First record of the occurrence of 'gill disease' in Mytilus edulis trossulus from the Gulf of Gdańsk (Baltic Sea, Poland). Journal of Invertebrate Pathology, 93, 207-209.

Smolarz K., Berger A. (2009). Long-term toxicity of hexabromocyclododecane (HBCDD) to the benthic clam Macoma balthica (L.) from the Baltic Sea. Aquatic Toxicology, 95, 239-247.

Sokołowski A., Wołowicz M., Hummel H., Smolarz-Górska K., Fichet D., Radenac G., Namieśnik J. (2004). Abnormal features of Macoma balthica (Bivalvia) in the Baltic Sea: altering symptoms of environmental adversity? Marine Pollution Bulletin , 49, 17-22.

Sunila I., Farley C. A. (1989). Environmental limits for survival of sarcoma cells from the soft-shell clam Mya arenaria .Diseases of Aquatic Organisms, 7, 111-115.

Thriot-Quiévreux C., Wołowicz M. (1996). Karyologic study of gill neoplasia in Macoma balthica (Mollusca, Bivalvia). Comptes Rendus de l'Academie des Sciences - Series III , 319, 887-892. 
Thriot-Quiévreux C, Wołowicz M (2001) Chromosomal study of spatial variation of the prevalence of a gill neoplasia in Macoma balthica (L.) from the Gulf of Gdańsk (Baltic Sea). Ophelia 54: 75-81

Ujvari B., Papenfuss A. T., Belov K. (2015). Transmissible cancers in an evolutionary context. Inside the Cell, 1, 17-25.

Väinölä R. (2003). Repeated trans-Arctic invasions in littoral bivalves: molecular zoogeography of the $M a$ coma balthica complex.Marine Biology , 143, 935-946.

Wołowicz M., Smolarz K., Sokołowski A. (2005). (Neoplasia in estuarine bivalves: effect of feeding behaviour and pollution in the Gulf of Gdansk (Baltic Sea, Poland) (inn: The comparative roles of suspension-feeders in ecosystems , 165-182, Springer, Dordrecht).

Yonemitsu M. A., Giersch R. M., Polo-Prieto M., Hammel M., Simon A., Cremonte F., Avilés F. T., MerinoVéliz N., Burioli E. A. V., Muttray A. F., Sherry J., Reinisch C., Baldwin S. A., Goff S. P., Houssin M., Arriagada G., Vázquez N., Bierne N., Metzger M. J. (2019). A single clonal lineage of transmissible cancer identified in two marine mussel species in South America and Europe. eLife, 8, e47788.

Yurchenko A. A., Katolikova N., Polev D., Shcherbakova I., Strelkov P. (2018). Transcriptome of the bivalve Limecola balthica L. from Western Pacific: a new resource for studies of European populations.Marine Genomics , 40, 58-63.

Zaborska A., Siedlewicz G., Szymczycha B., Dzierzbicka-Głowacka L., Pazdro K. (2019). Legacy and emerging pollutants in the Gulf of Gdańsk (southern Baltic Sea) - loads and distribution revisited. Marine Pollution Bulletin, 139, 238-255.

\section{Data accessibility and Benefit-Sharing Statement}

Sequence alignment of $m t C O I$ and E $\Phi 1 a$ loci are supplied in Supplementary Information and raw sequence reads will be deposited in the GenBank upon the time of publishing.

Benefits Generated: This research developed as part of international, multi-institutional collaboration. The research provided an opportunity for international student's internship therefore contributing to education and training. The training was also related to genetic resources with the full participation of Polish side of the research, providing new genetic data. All scientific information obtained within this study is accessible and is relevant for marine population studies. This research can provide as opportunity for institutional and professional relationships that will arise from an access and benefit-sharing agreement and subsequent collaborative activities.

\section{Author Contributions}

Alicja Michnowska - writing and editing manuscript, data acquiring and interpretation, sample collection and processing, conceptualisation

Samuel Hart - data acquiring and interpretation, manuscript editing

Katarzyna Smolarz - fund raiser, manuscript editing, sample collection and processing, conceptualisation

Anna Hallmann - manuscript editing, sample collection

Michael Metzger - writing and editing manuscript, data acquiring and interpretation, conceptualisation, fund raiser

Tables and Figures 


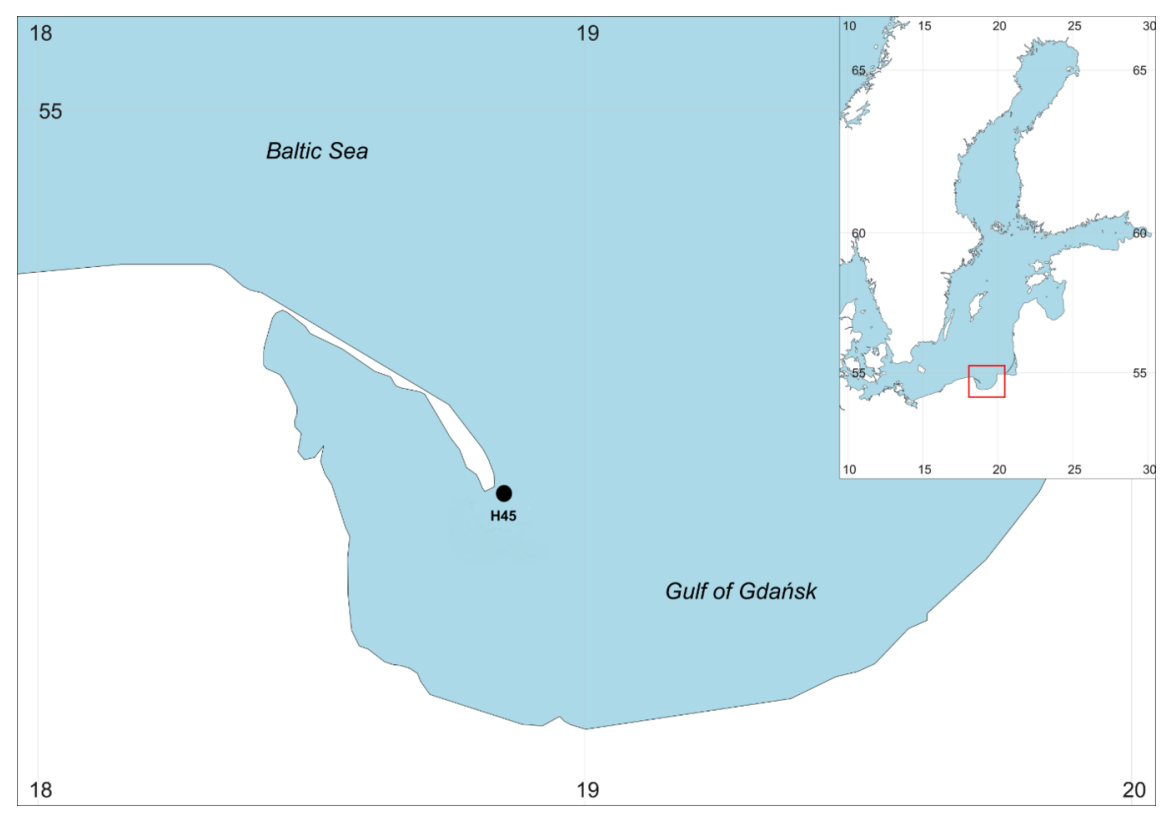

Fig. 2.1. Location of L. balthica sampling site. Map was generated using SimpleMappr (Shorthouse 2010).

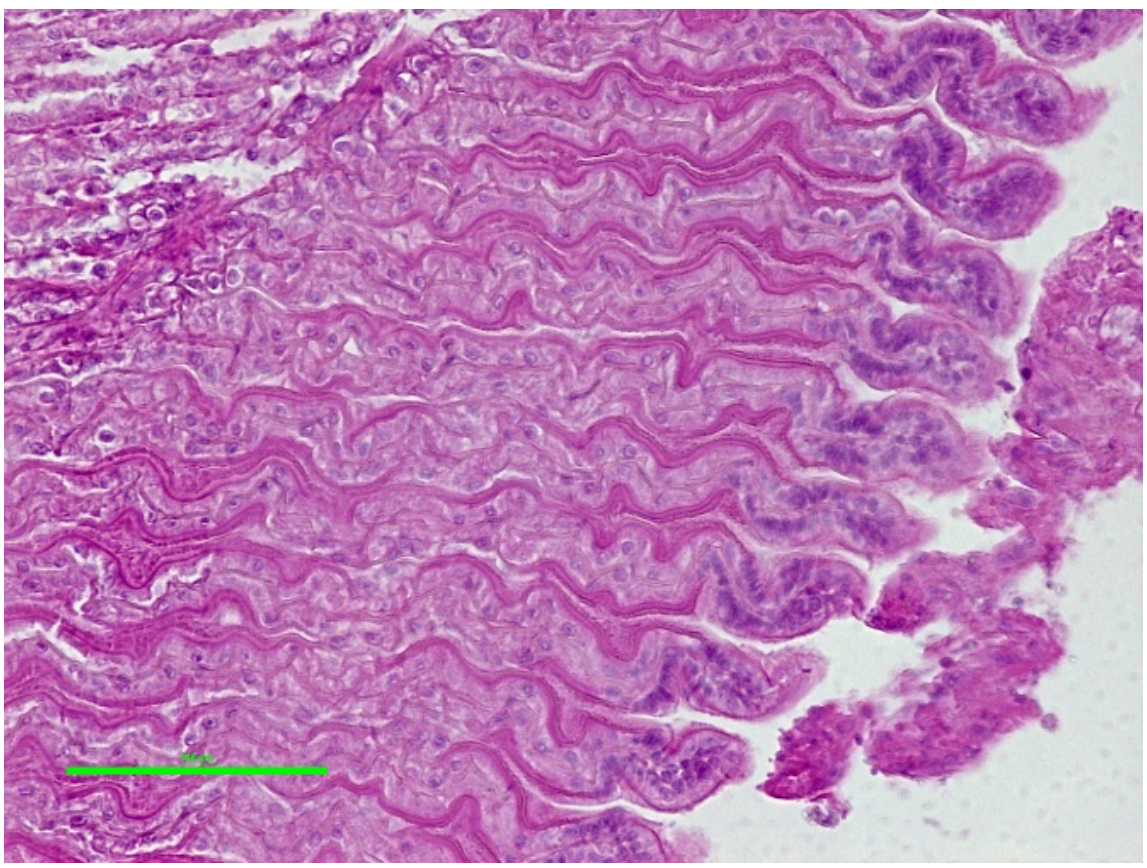




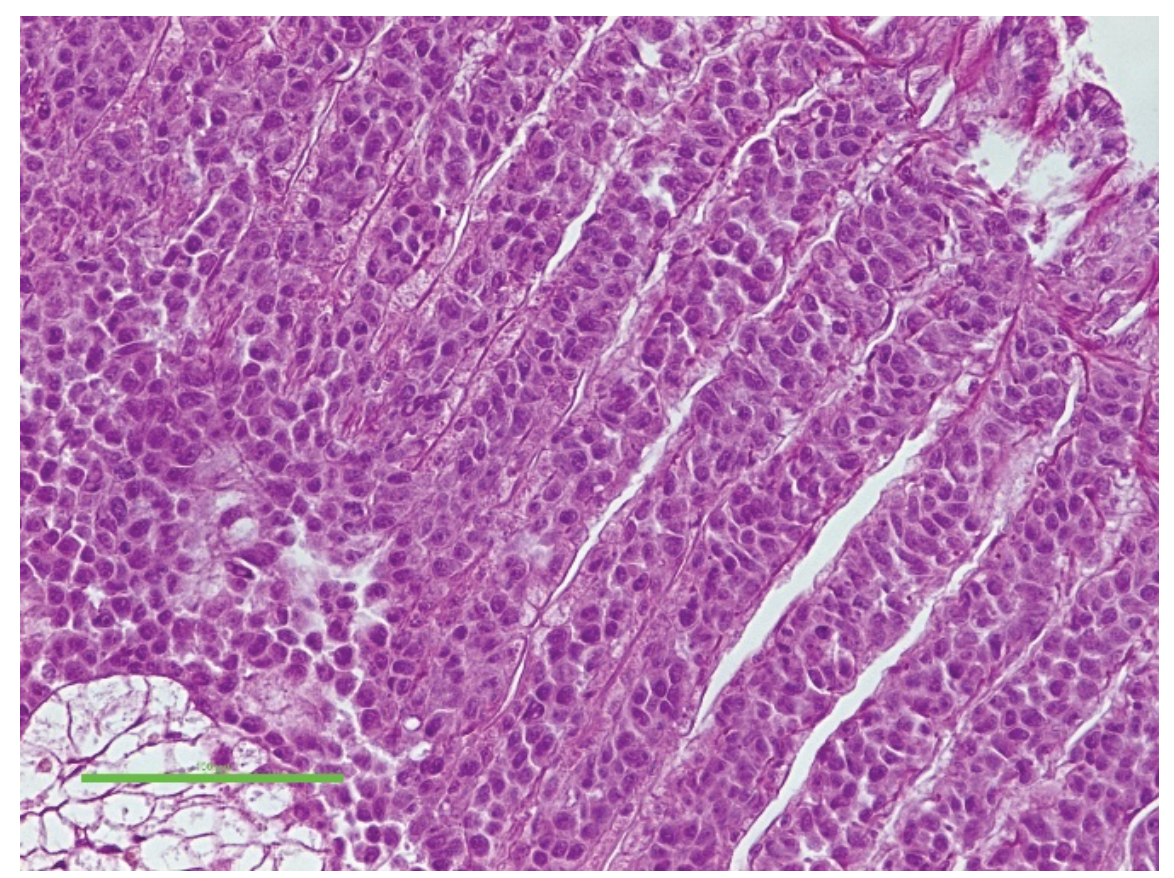

Fig. 2.2. Histological representation of gills from healthy (individual \#88, left) and neoplastic (individual \#158, right)L. balthica, H\&E staining. Note the amount of highly hematoxylin-stained cells destroying tissue structure in neoplastic individual. Photographed under light microscope, x200.

Tab. 2.3. PCR primers used for amplification and sequencing.

\begin{tabular}{|c|c|c|c|c|}
\hline Locus & Forward primer & Reverse primer & Annealing $\left({ }^{\circ} \mathrm{C}\right)$ & Size (bp) \\
\hline \multirow[t]{3}{*}{$\overline{E \Phi 1 a}$} & SHO-086 & SHO-088 & 50 & 903-920 \\
\hline & _limecola_EF1_F & _limecola_EF1_R7 & & \\
\hline & CTTGACCTCAC & GGTCTGGTGGTG & CAAAGGT & \\
\hline \multirow[t]{2}{*}{$m t C O I$} & LCO1490Mba & HCO2198Mba & 50 & $\sim 655$ \\
\hline & GTAGAACTAAY & ANARAATACXIGG & GRCCAAAAAA & \\
\hline
\end{tabular}




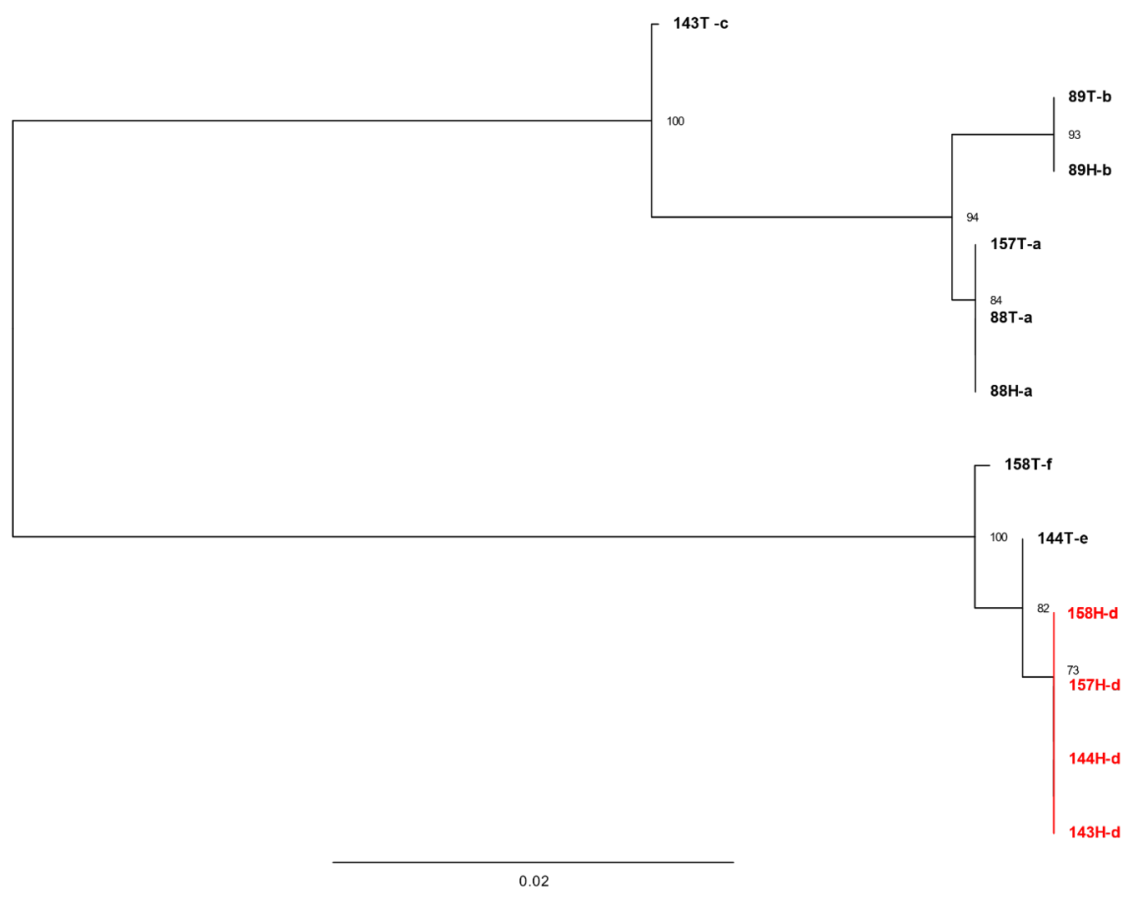

Fig. 3.1. Phylogenetic tree of $m t C O I$ sequences from healthy $(88,89)$ and neoplastic $(143,144,157,158)$ L. balthicaindividuals. Numbers above the nodes indicate bootstrap values; values below 50 are not shown. Common cancer lineage observed in several neoplastic clams is highlighted in red. Scale bar represents genetic distance between sequences. $\mathrm{T}$ or $\mathrm{H}$ : sequence obtained from solid tissue $(\mathrm{T})$ or haemolymph $(\mathrm{H})$ of each clam; b-f - allele labels.

Tab. 3.1. mtCOI alleles associated with haemolymph $(\mathrm{H})$ and host solid tissue $(\mathrm{T})$ found in tested individuals, cancer-associated allele is highlighted in red.

\begin{tabular}{lll}
\hline & $\mathrm{T}$ & $\mathrm{H}$ \\
\hline 88 healthy & $\mathrm{a}$ & $\mathrm{a}$ \\
89 healthy & $\mathrm{b}$ & $\mathrm{b}$ \\
143 neoplastic & $\mathrm{c}$ & $\mathrm{d}$ \\
144 neoplastic & $\mathrm{e}$ & $\mathrm{d}$ \\
157 neoplastic & $\mathrm{a}$ & $\mathrm{d}$ \\
158 neoplastic & $\mathrm{f}$ & $\mathrm{d}$ \\
\hline
\end{tabular}




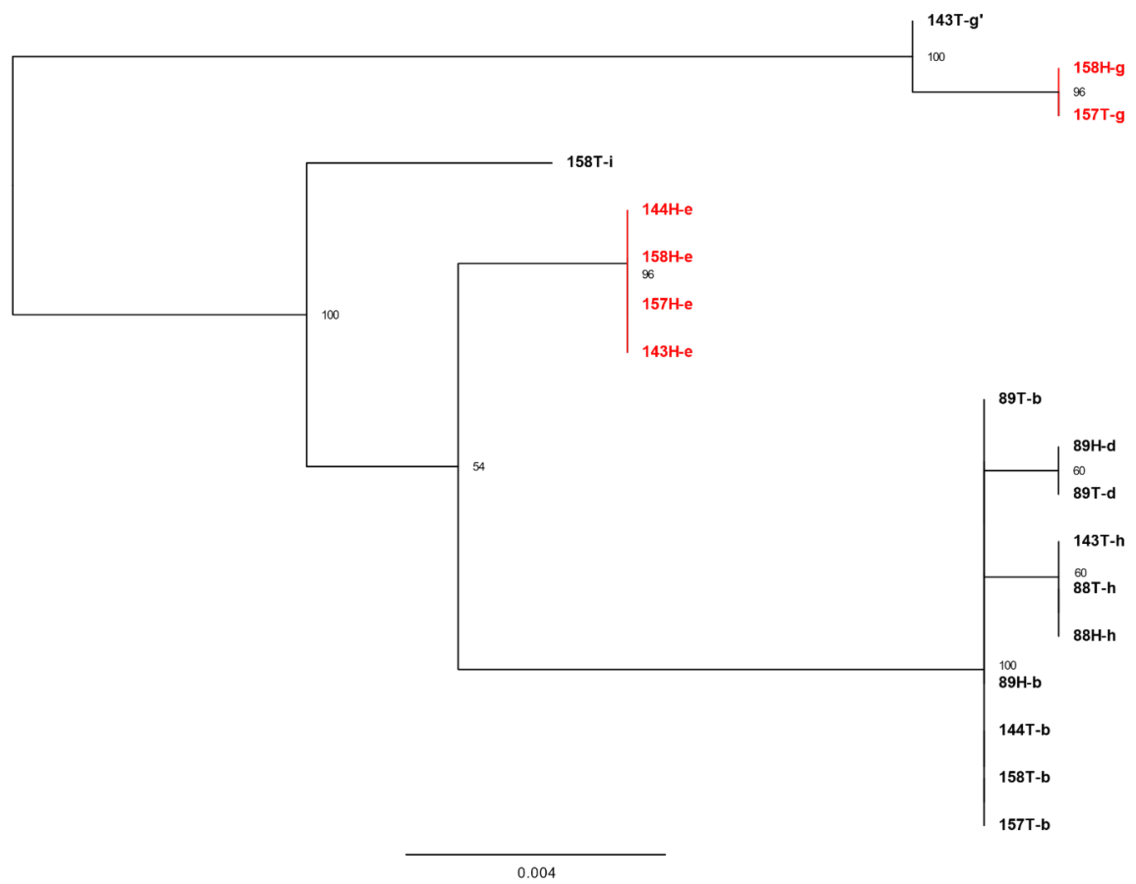

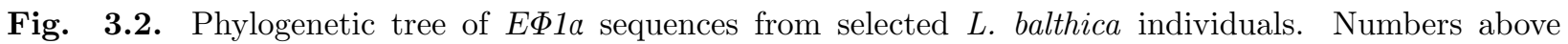
the nodes indicate bootstrap values; values below 50 are not shown. Common cancer lineage observed in several neoplastic clams is highlighted in red. Scale bar represents genetic distance between sequences. H haemolymph; $\mathrm{T}$ - host tissue; b-i - allele labels.

Tab. 3.2. EF $1 \alpha$ alleles associated with haemolymph $(\mathrm{H})$ and host's solid tissue $(\mathrm{T})$ found in analyzed individuals, cancer-associated allele is highlighted in red.

\begin{tabular}{lll}
\hline & T & H \\
\hline 88 healthy & h & h \\
89 healthy & b, d & b, d \\
143 neoplastic & h, g' & e \\
144 neoplastic & b & e \\
157 neoplastic & g, b & e \\
158 neoplastic & b, i & e, g \\
\hline
\end{tabular}

\section{Hosted file}

Fig.2.1.eps available at https://authorea.com/users/458838/articles/555302-horizontaltransmission-of-disseminated-neoplasia-in-the-widespread-clam-limecola-balthica-fromthe-southern-baltic-sea 

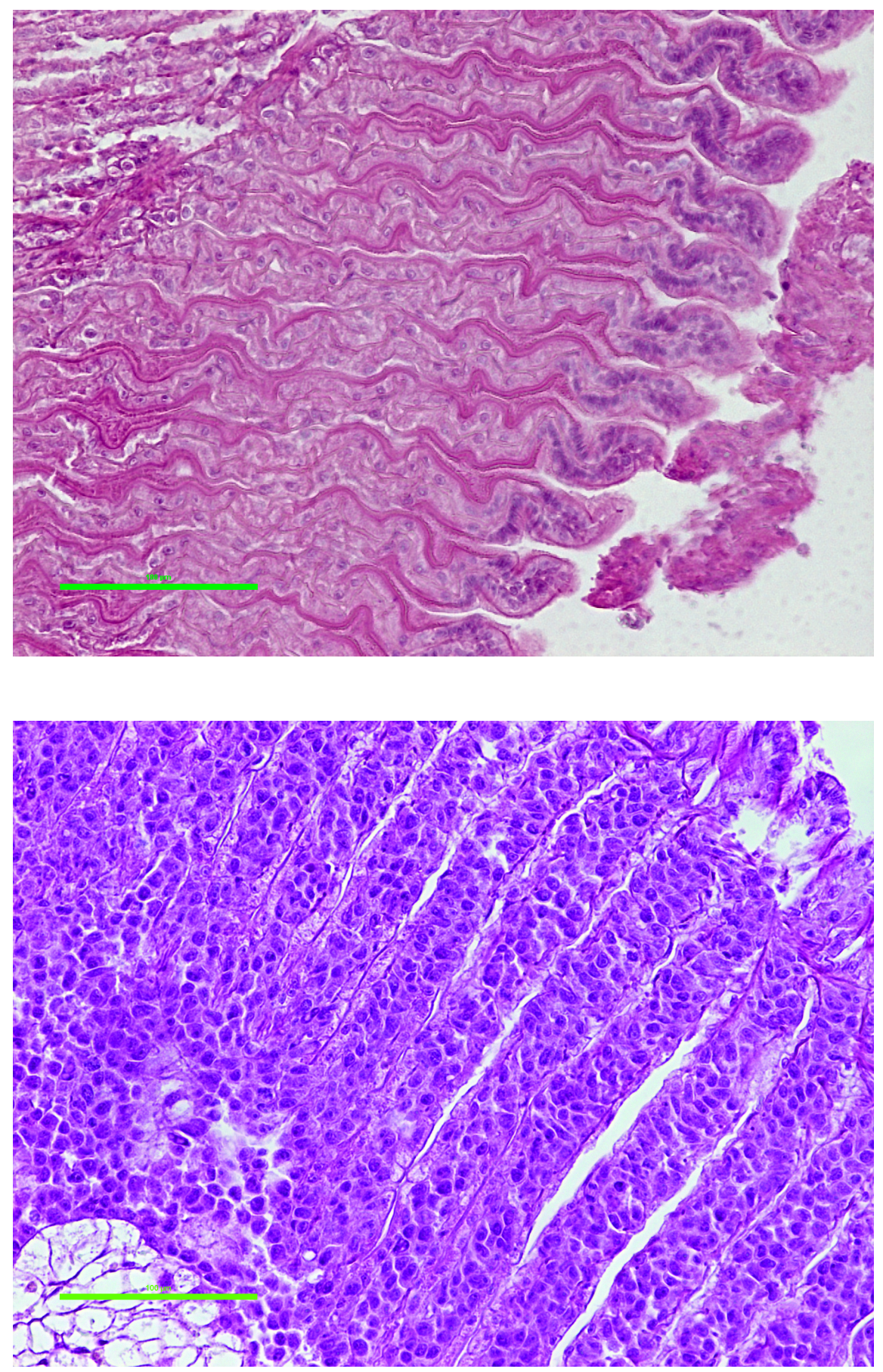

\section{Hosted file}

Tab.2.3..docx available at https://authorea.com/users/458838/articles/555302-horizontaltransmission-of-disseminated-neoplasia-in-the-widespread-clam-limecola-balthica-fromthe-southern-baltic-sea

\section{Hosted file}


Fig.3.1.eps available at https://authorea.com/users/458838/articles/555302-horizontaltransmission-of-disseminated-neoplasia-in-the-widespread-clam-limecola-balthica-fromthe-southern-baltic-sea

\section{Hosted file}

Tab. 3.1..docx available at https://authorea.com/users/458838/articles/555302-horizontaltransmission-of-disseminated-neoplasia-in-the-widespread-clam-limecola-balthica-fromthe-southern-baltic-sea

\section{Hosted file}

Fig.3.2.eps available at https://authorea.com/users/458838/articles/555302-horizontaltransmission-of-disseminated-neoplasia-in-the-widespread-clam-limecola-balthica-fromthe-southern-baltic-sea

\section{Hosted file}

Tab.3.2.docx available at https://authorea.com/users/458838/articles/555302-horizontaltransmission-of-disseminated-neoplasia-in-the-widespread-clam-limecola-balthica-fromthe-southern-baltic-sea 